\title{
EL MUNICIPIO CONSTITUCIONAL EN LA ESPAÑA DE 1812
}

ENRIQUE ORDUÑA REBOLLO 


\section{SUMARIO}

1. ENTRE EL CAMBIO INSTITUCIONAL O LA RUPTURA. a) La fugaz legislación municipal de José I. b) El Decreto josefino de división en prefecturas y gobierno municipal 2. LOS MUNICIPIOS EN LOS ALBORES DEL CONSTITUCIONALISMO ESPAÑOL. a) La Comisión de Constitución y la Consulta al País. b) El Decreto josefino de división en prefecturas y gobierno municipal. c) Los Ayuntamientos en la tramitación del Proyecto de Constitución de 1812. d) Los Ayuntamientos en el texto constitucional. e) El efímero desarrollo constitucional de la legislación de los Ayuntamientos. f) La extensión de los Ayuntamientos Constitucionales. 


\title{
EL MUNICIPIO CONSTITUCIONAL EN LA ESPAÑA DE 1812
}

POR

\author{
ENRIQUE ORDUÑA REBOLLO
}

Secretario General del OICI

\section{ENTRE EL CAMBIO INSTITUCIONAL O LA RUPTURA}

Se nos ha planteado en diversas ocasiones la opción entre dos coyunturas que se ofrecieron en aquellos años de crisis. ¿Ruptura o cambio institucional?, en terminología de nuestros días. Forzosamente debemos inclinarnos, al menos en lo que se refiere a municipios y provincias, por la segunda de las opciones ${ }^{1}$. Indudablemente el propósito mayoritario que guiaba a los redactores de la Constitución era construir un nuevo régimen sobre las ruinas del antiguo que, como sabemos, tampoco se resignaba a desaparecer,

De otro lado es evidente que los doceañistas eran en su mayoría personas de cultura y orientación europea, como señala Posada, que sentían la necesidad apremiante de una amplia, quizá total, transformación del Estado ${ }^{2}$. También es cierto que algunos se encontraban directamente influidos por los postulados de la revolución francesa, lo que se transmitirá y plasmará en la Constitución y desde ésta a la Administración Pública en general, como ha estudiado García de Ente-

1 Orduña Rebollo, E.: «El cambio Institucional», en: Oligarquía y Caciquismo. Historia de Castilla y León. Valladolid. Ambito. 1986, vol. IX, págs. 126-143.

2 Posada, A.: « Evolución legislativa del régimen local en España. 1812-1909», 2a ed., Madrid. IEAL, 1982, pág. 48. 
rría $^{3}$. Sin olvidar las influencias de la Constitución inglesa en los desarrollos legislativos posteriores, al haber sido Inglaterra refugio de muchos doceañistas durante los años del absolutismo ${ }^{4}$.

Trataban sin duda de transformar y cambiar las instituciones, adaptando las tradiciones a las necesidades de la sociedad y de la época. Lo que es indudable, y así lo confirman los tratadistas y estudiosos antiguos y modernos, Martínez Marina, Toreno, Posada S. Martín Retortillo, Artola, García Fernández, Gallego Anabitarte, Morell, Sosa, etc, es que en ningún momento se producirá una total ruptura institucional, ni en el curso de los debates ni tampoco en los períodos que el texto constitucional de 1812 estuvo en vigor.

Ahora bien, con las inspiraciones basadas en la tradición española y otras procedentes de la revolución francesa, principalmente Montesquieu y la Constitución de 1791, se procedió a sustituir la inservible estructura institucional del Antiguo Régimen. Posada señala a este respecto que se produjo un distanciamiento entre el contenido del Discurso preliminar y el articulado, por la influencia más directa de la Constitución francesa de 1791 y en ocasiones de la inglesa 5 . Este aspecto se manifiesta con mayor énfasis al regular la organización de las Cortes, como reconoce el propio Martínez Marina, cuando señala las ventajas de la representación nacional proporcionada a la población, respecto al sistema tradicional, pues «en lo antiguo no se guardaba esta igualdad, porque las elecciones se hacian en razón del número de concejos y no del de habitantes» ${ }^{6}$.

En la administración local española moderna vamos a encontrar junto a una clara influencia de la tradición municipalista medieval castellana, basada en las libertades y la autonomía local, indudablemente sobrevalorada y exaltadas, un importante componente de inspiración francesa que analizó García de Enterría, en el sentido de que se sustituye el orden estamental por «el principio de un orden social nuevo, de territorialidad de los derechos sociales y de borizontalidad uniforme en su distribución»?

Este cambio institucional quedó respaldado por dos importantes actuaciones: la Consulta al País en 1809 y la supresión del sistema señorial en 1811. En el caso de la primera los consultados, manifestaban un deseo generalizado de que el

3 Garcia de Enterria, E. Revolución francesa y Administración contemporánea. Madrid,. 1972, pág. 32.

4 LLORÉNS, V.: «Liberales y románticos. Una emigración española en Inglaterra. 1823-1834», $3^{a}$ ed. Valencia. Castalia. 1979.

5 Posada, A.: «Tratado de Derecho Político». Madrid. 1916, pág. 269.

${ }^{6}$ Martinez Marina, F.: «Teoría de las Cortes». Madrid. 1976, vol. I. págs. 206 y ss.

7 Garcia de Enterria, E.: «Turgot y los orígenes del unicipalismo moderno». Madrid. RAP, núm. 33, pág. 86. 
Ayuntamiento surgido de la futura Constitución debía ser una institución nueva, sin vínculos con modelos pretéritos, dotada de una organización diferente. Coinciden algunos comunicantes en la necesidad de que existiesen alcalde y regidores en los pueblos en función de su número de habitantes, previniendo que los más pequeños debían disponer, al menos, de alcalde pedáneo.

La representatividad democrática de los Ayuntamientos también fue objeto de atención por diversos consultados, pero la coincidencia resultó más unánime en las peticiones de supresión de los corregimientos de capa y espada, proponiendo su desaparición sin precipitaciones, para que el cargo de corregidor fuese ocupado exclusivamente por personas de formación jurídica al objeto de evitar la dependencia de empleados proclives a la corrupción ${ }^{8}$. En la supresión de los señoríos jurisdiccionales, junto a la unificación de los fueros, coincidieron todos los opinantes.

Resultaba evidente que en los primeros años del siglo XIX, España asiste a la crisis generalizada de las Instituciones del Antiguo Régimen, incluido un agotamiento ideológico y material del que sólo a duras penas se salvan los Municipios, y aunque configurados de acuerdo con pautas y sistema del Antiguo Régimen, capitalizaron la resistencia antifrancesa con mayor o menor fuerza y éxito. En consecuencia serían sometidos a la sospecha permanente, quedarían bajo la competencia de la autoridad militar de ocupación y posteriormente enmascarada la militarización de la vida cotidiana, serían reordenados de acuerdo con los principios napoleónicos ${ }^{9}$.

\section{a) La fugaz legislación municipal de José I}

Pese a todos los condicionantes negativos que tuvo la Constitución de Bayona, en el momento patriótico de su promulgación, no podemos obviar su influencia en determinados preceptos del texto español de 1812, en consecuencia continuaremos nuestro comentario con una mención a ella. Según diversas referencias, la iniciativa de dotar al pueblo español de una Norma Fundamental correspondió a Murat, que sugirió al Emperador su conveniencia. Inspirada en los principios franceses del momento, fiel reflejo de las ideas que sobre España y su gobernación tenía el propio Napoleón, imponiéndose al criterio de su hermano José y a los tímidos intentos de los españoles afrancesados que participaron en las sesiones, y que consiguieron introducir con dificultad algunas aportaciones al

${ }^{8}$ Fernández García, J.: «El origen del Municipio Constitucional». Madrid. IEAL, 1983, pág. 223.

9 Orduña Rebollo, E. Municipios y provincias... op. cit., pág. 264. 
texto en los debates bayoneses. Coinciden diversos autores en que se reprodujo el modelo de las Constituciones del Consulado y del Imperio, textos franceses de los años VIII, X y XII de los que habían desaparecido las referencias a los Munici$\operatorname{pios}^{10}$.

Por tanto, no debe sorprender que la Constitución de Bayona, promulgada en dicha ciudad el 7 de julio de 1808, las referencias a los Municipios sólo se encuentran en el Título IX, referido a las Cortes, que en su artículo 68 prevé la existencia de una junta para elegir el diputado de partido, encomendando provisionalmente al decano de los regidores de todo pueblo que tuviese más de cien habitantes para dar un elector. Más concreto es el artículo 71 referido a la elección de los diputados de las 30 ciudades principales del Reino, que serían nombrados por el Ayuntamiento de cada una de ellas. En el título X, «De los reinos y provincias españolas de América y Asia», el artículo 93, determina que los veintidós diputados de América y Asia, serían nombrados por los Ayuntamientos de los pueblos designados el virrey o el capitán general.

Bajo las negativas circunstancias de la intermitente permanencia de José Bonaparte en Madrid, acosado por los patriotas españoles y por el intervencionismo del Emperador, una de sus preocupaciones, creemos que más para asentar su frágil poder, que para evitar los atropellos de los generales franceses, fue el nombramiento de comisarios regios en las provincias, con instrucciones para organizar los Ayuntamientos y facultándoles para nombrar y destituir a los cargos municipales ${ }^{11}$.

El siguiente paso fue la promulgación de dos Decretos el 21 de agosto de 1809, para regularizar la situación municipal de Madrid. El primero disponía la creación de «una Municipalidad en Madrid y se señalan las funciones del corregidor». El Ayuntamiento de la villa se compondría de un corregidor, 16 regidores, un procurador del común, un sustituto del procurador y un escribano secretario. Sin determinar el procedimiento sólo estaba prevista la elección de los regidores, con lo que se abría un resquicio a la participación popular, aunque fuese de carácter censitario, confirmado por el artículo $4^{\circ}$ que extinguió los oficios perpetuos, quizá los dos aspectos más positivos de la norma referenciada.

El intervencionismo centralizador no podía dejar resquicios a la autonomía municipal, por lo que el segundo de los Decretos de la misma fecha «en que se reúnen a la Real Hacienda los derechos y sisas municipales de Madrid, cuyos acreedores lo

10 García Fernández, J. El Origen... op. cit., pág. 192.

11 Prontuario: «Prontuario de las Leyes y Decretos del Rey Nuestro Señor don José Napoleón I, del año 1809». Madrid. Imprenta Real. 1809, vol. I. págs. 310 y 311. Decreto de 6 de febrero de 1809). 
serán del Estado» suponía realmente el establecimiento de un régimen de tutela financiera y en la práctica la anulación de la Hacienda municipal madrileña, al ser privada de recursos tributarios propios ${ }^{12}$.

Tampoco aportó mayores novedades el Decreto de 4 de septiembre de 1809 «para la creación de nuevas municipalidades en todo el reyno, y obligación que se impone a los jueces, abogados y escribanos de presentar sus títulos», que entendemos responde a la situación de excepcionalidad existente, no sólo por el hecho de reunir en una misma norma cuestiones tan dispares, sino al disponer también la disolución de todos los antiguos Ayuntamientos, cuyos actos era declarados nulos y ordenaba a los Intendentes y gobernadores que constituyesen los nuevos Ayuntamientos, de acuerdo con el espíritu contenido en el Decreto.

\section{b) El Decreto josefino de división en prefecturas y gobierno municipal}

La convulsión producida por la guerra a partir de 1808, complicó notablemente el panorama de la organización territorial española por las propias oscilaciones bélicas producidas por las alternancias en la ocupación del territorio. Por lo que hemos de mencionar la división de 1810 realizada por el invasor, que estuvo en vigor mientras el ejército francés controló el territorio ocupado. Se trata del Decreto dictado en Sevilla por José Bonaparte el 17 de abril de 1810, estableciendo la división del gobierno civil de los pueblos del Reino en Prefecturas y la demarcación de sus límites. El mencionado Decreto dividió a España en treinta y ocho Prefecturas y setenta y cuatro subprefecturas.

El Decreto, «por el que se establece la división del gobierno civil de los pueblos del reyno en prefecturas, y demarcación de sus límites» es el intento legislativo de carácter local más importante de José Bonaparte. Se articula en un Título primero sobre la «División del Reyno» en prefecturas, los Títulos II y III «De las prefecturas»y «Subprefecturas», el Titulo IV «De las Municipalidades» y el V referido a «Sueldos».

Las razones políticas de este Decreto, las atribuye García Fernández, a la reacción de José Bonaparte al Decreto imperial de 8 de febrero de 1810, por el que se establecieron gobiernos militares en los territorios situados al este del Ebro, que sería considerado como grave atentado al poder y a la soberanía del nuevo rey, al ocultar una posible desmembración del territorio de España y agregar algunas provincias a Francia ${ }^{13}$. Coincidían tales propósitos con la presencia en Valladolid del mariscal Junot, que actuaba con el título de Regente Gobernador de la Alta España, por lo que cabía suponer que Napoleón pretendía desmembrar de

12 García Fernández, J. El Origen... op. cit., pág. 197

13 Ibidem, pág. 199. 
España «el Señorío de Vizcaya y Provincias de Guipúzcoa y Álava, quedando sujetas y unidas a Francia» ${ }^{14}$.

Por tanto nos encontramos con una propuesta de organización del territorio de la Monarquía Josefina, en sus diversos niveles, incluido el municipal. De hecho las Subprefecturas se dividían en Municipalidades, debiendo determinarse posteriormente por Decretos particulares sus límites y el número de Municipalidades, atendiendo sus circunstancias locales ${ }^{15}$.

El modelo de Municipio contenido en el Decreto, se caracteriza por responder al del Municipio napoleónico perfilado en los Decretos del año anterior. Impregnado de un fuerte centralismo, estaba opuesto a cualquier atisbo de autonomía municipal, situando al prefecto y al subprefecto en el orden jerárquico los superiores al Municipio.

Entre las atribuciones del Prefecto figuraban «La vigilancia sobre la dirección e inversión de los bienes y rentas pertenecientes a las Municipalidades..." «Los empleados municipales y la policía urbana» ${ }^{16}$. Aquí hemos de referirnos a la existencia de una larga relación de competencias del Prefecto, que tradicionalmente habían sido asumidas por los Ayuntamientos, como beneficencia, hospitales, salud pública, hospicios, casas de misericordia, instrucción pública, y otras diversas relativas al fomento. En resumen las Municipalidades no tenían competencias propias y para las actividades que podían ejercer se requería la autorización del prefecto o del Consejo de Prefectura ${ }^{17}$. Esta posición de absoluta subordinación del Municipio respecto al Prefecto, se confirmaba en el art. $1^{\circ}$ del Titulo IV dedicado a las Municipalidades, al disponer que en lo referente a su gobierno interior dependerán únicamente del Prefecto, baxo las órdenes de nuestro Ministro de lo Interior.

Los intereses particulares de la Municipalidad se trataban por medio de una Junta municipal, designada en Concejo Abierto por los vecinos contribuyentes de la misma Municipalidad. Esta figura no debe inducir a engaño y suponer la existencia de un principio de democracia local, nada más lejos del propósito francés. En primer lugar se trataba de un procedimiento censitario, donde sólo eran electores los contribuyentes que superasen un determinado nivel de renta. Además de este requisito se exigía el de adhesión incondicional al usurpador, acatar la Constitución de Bayona y por supuesto estar considerada como persona de con-

14 Almunia, C. Nacimiento y configuración de la nueva sociedad vallisoletana. De la vieja sociedad estamental al triunfo de la «burguesía harinera». En: Valladolid en el siglo XIX. Valladolid. Arteneo, 1985, pág. 97.

15 Prontuario... op. cit., 1810, vol. II, pág. 61, art. IV.

16 Ibidem, pág. 62, art. II.

17 Vallina Velarde, J. L.: «La competencia administrativa y su ejercicio». Madrid. Documentación Administrativa. núm. 70, 1963, pág. 26. 
fianza del comandante militar de la plaza, por lo que el sentido democrático municipal, como se entiende en el Concejo Abierto, quedaba absolutamente en entredicho y desfigurado.

El contenido de la reforma municipal josefina lo esquematiza García Fernández en seis conceptos, que reúnen los aspectos más significativos de la mencionada reforma:

a) Sufragio censitario, dadas las circunstancias restrictivas, ya hemos manifestado nuestra opinión sobre su componente democrático.

b) Representatividad del corregidor y los regidores, se culmina el proceso intervencionista y carente de democracia al ser designados por la Junta correspondiente.

c) Limitaciones al régimen de sesiones de las Juntas municipales. No son precisas al no existir competencias y sólo obligaciones regladas y puntuales.

d) Tutela financiera. Se limitan a formar el presupuesto, su aprobación corresponde a las instancias superiores.

e) Régimen de autorizaciones previas. Cualquier decisión municipal que afectase a su patrimonio, requería el permiso del prefecto, del Ministro del Interior o del monarca.

f) Personalización del poder municipal en el Corregidor. Adquiere un carácter presidencialista, pues los regidores se limitan a ser meros colaboradores en su gestión ${ }^{18}$.

Como conclusión debemos señalar que además de los graves condicionantes políticos y bélicos, esta norma destilaba el más absoluto intervencionismo en los Municipios, convirtiéndoles en entidades carentes de autonomía, y cuyas cotas democratizadoras eran tan mínimas que no pasaban de una manifestación de intenciones. En un sentido algo más positivo hemos de señalar la exclusión de atribuciones judiciales a los Corregidores, según estaba previsto en la Constitución de Bayona, con lo que se configuraba la separación de poderes y que sería confirmado por el Decreto de 5 de Noviembre de 1810, «Por el que se fixan las atribuciones de los Jueces de primera instancia y de los Corregidores», ordenando que los Jueces de primera instancia y Alcaldes mayores, sólo conocerían las primeras demandas judiciales y «no tendrán intervención alguna en el gobierno de los pueblos», por otra parte los Corregidores «cuidarán únicamente del gobierno de las Municipalidades» ${ }^{19}$.

18 García Fernández, J. El Origen.... op. cit., págs. 204 a 208.

19 Prontuario... op. cit., pág. 252. 


\section{LOS MUNICIPIOS EN LOS ALBORES DEL CONSTITUCIONALISMO ESPAÑOL}

Como se ha dicho en reiteradas ocasiones, en 1812, existía una coincidencia para reformar el régimen local y acabar con la venta de oficios, instaurando un sistema electivo más o menos indirecto, y sobre todo a los efectos que a nosotros interesa, abolir los señoríos jurisdiccionales, figura de dificilísima evaluación por su gran variedad y número, pues a título de ejemplo, la Audiencia de Galicia fijaba la pervivencia de 1.160 jurisdicciones en su territorio, de las cuales sólo 45 eran de realengo, sin olvidar que sólo el 47,14\% según Anes del total de las entidades territoriales de la España peninsular e insular, en 1789, eran de realengo ${ }^{20}$.

Frente a la existencia de la jurisdicción plural de carácter señorial, la Constitución de Cádiz trató de reducirla de manera uniforme, extendiendo Ayuntamientos por todo el reino con la consiguiente abolición de cualquier privilegio ${ }^{21}$. Para ello, el artículo 310 del texto doceañista preveía la existencia de Ayuntamientos en los pueblos que no los hubiese y fuese conveniente su existencia, siendo obligatoria para los que por sí o por su «comarca lleguen a mil almas».

Este loable criterio justificó el posible defecto imputado a los legisladores gaditanos, que pese a su profesión de fe historicista y el canto dedicado a las tradiciones locales españolas contenido en el discurso preliminar, en el articulado no desarrollaron dichos criterios, ni por tanto se adoptó el modelo de Municipio histórico, más acorde con la costumbre española y que debidamente adaptado al marco constitucional disfrutase de mayor autonomía; por el contrario, optaron por crear Ayuntamientos dedicados casi exclusivamente a colaborar con el Poder central en sus funciones administrativas, aunque quizá las circunstancias no permitieron otra opción. A consecuencia de ello quedó sin resolver la situación administrativa de numerosos pueblos y lugares que no alcanzaron la categoría de

20 Además de la mencionada obra de Anes, recordemos: Clavero Salvador, B. Propiedad feudal en Castilla (1369-1836). Madrid. 1973. Moxo, S de. Incorporación de señoríos a la Corona. Valladolid. 1959. Sempere y Guarinos, J. Historia de los vínculos y mayorazgos. Madrid.1805.

21 Sobre la Constitución de 1812 existe una amplia bibliografía, a título orientativo: CLAVERo SAlvador, B. Evolución histórica del constitucionalismo español. Madrid. Tecnos 1984. Idem. Manual de Historia Constitucional de España. Madrid. 1988. Comellas, J. L. Las Cortes de Cádiz y la Constitución de 1812. Madrid. REP, núm. 162. 1962. Brewer Carias, A. R. Las Constituciones de Venezuela. Madrid. IEAL. 1985. García Fernández, J. Esquemas del constitucionalismo español. 1808-1976. Madrid. 1976. MARTinez Sospedra, M. La Constitución de 1812 y el primer liberalismo español. Valencia 1979. Sevilla AnDres, D. Historia política de España. Madrid. 1968., etc. 
Ayuntamientos y fueron reducidos a la condición de unidades electorales para la formación de aquellos ${ }^{22}$.

\section{a) La Comisión de Constitución y la Consulta al País}

Revisadas las tímidas reformas municipales introducidas en 1766 por Carlos III, y los intentos de organización municipal de José I, de acuerdo con el contenido municipal del modelo francés previsto en las Constituciones del Imperio, la continuidad cronológica de los acontecimientos históricos nos obliga a analizar los planteamientos previos a la elaboración de la Constitución de 1812, y su incidencia directa e inmediata en el tema objeto de nuestro estudio: el Municipio Constitucional.

La Junta Central, que actuaba como gobierno en la España no ocupada por los franceses, pese a las dificultades y la situación excepcional que afectaba a la Nación, promulgó el Decreto de 22 de mayo de 1809, haciendo publica la convocatoria de Cortes y en el que se preveía la creación de una Comisión de cinco vocales «que con toda la atención y diligencia... reconozcan y preparen todos los trabajos y planes ... han de servir para la convocación y formación de las primeras Cortes ${ }^{23}$.

Esta Comisión creó diversas Juntas, entre ellas la de Legislación, con el objeto de «examinar y proponer a la Comisión todas las reformas que crea deben ejecutarse en las diferentes partes corporales de que se compone el todo de nuestra legislación...». Dicha Junta debería observar «dos máximas muy importantes: una que las leyes que propusiese sean conformes al espiritu de las ya establecidas, y otra que sean pocas y claras, para que la observancia sea más segura». La misma Instrucción la autorizaba para introducir una sola alteración, consistente en suprimir lo que afectase a la unidad de la constitución política de la Monarquía, en referencia a «las varias constituciones municipales y privilegiadas de algunos pueblos y provincias que son partes constituyentes del cuerpo social», por la manifiesta situación de desigualdad en las obligaciones y derechos de los ciudadanos ${ }^{24}$.

Con estos precedentes, los trabajos de la Junta se desarrollaron hasta el 14 de enero de 1810, estudiando una serie de «cuestiones» aprobadas a partir de unas bases preparadas por Jovellanos, quien tuvo una gran influencia y permanente protagonismo en las actividades de la Comisión. El último acuerdo tomado el 14

22 Parejo Alfonso, L.: «La región y la legislación histórica de régimen local», en Las Autonomías regionales en España. Madrid. Instituto Nacional de Prospectiva. 1977, pág. 31.

23 SuÁrez Verdaguer, F. El proceso de convocatoria a Cortes (1809-1810). Pamplona, EUNSA, 1982, pág. 133.

24 Ibidem, pág. 253. 
de enero se refería al «arreglo administrativo de las provincias para la repartición y recaudo de las contribuciones directas, inversión de Propios y Arbitrios, fomento de la agricultura e industria, construcción y reparación de caminos, puentes y demás medios de comunicación» competencias que estarían a cargo de una Diputación que se crearía en cada provincia «según el arreglo que se hará mas adelante». También se proponía la libre elección por los pueblos de sus ayuntamientos, según la idea de estructurar España en una realidad nacional ${ }^{25}$.

Es necesario hacer una mención más extensa a La Consulta al País, gestada desde el 22 de mayo de 1809 cuando la Junta Central creó por Decreto la Comisión de Cortes, y entre las cuestiones que la encomendó figuraba una amplia consulta a instituciones, entidades públicas o privadas, autoridades, etc. para que informasen todo lo que considerasen oportuno sobre la forma de constituirse las futuras Cortes y las cuestiones que deberían ser tratadas por éstas. El desarrollo de esta demanda de información, conocida como «La Consulta al País», está contenido en la Circular de 24 de Junio. En ella se pedía a los Ayuntamientos que informasen de los antecedentes que existiesen en sus archivos sobre la convocación de Cortes, elección de Procuradores, poderes e instrucciones que llevaban, procedimientos a seguir para las proposiciones y peticiones que hacían al soberano, ya con los demás Procuradores o con el resto de los brazos militar, eclesiástico o noble, así como la existencia en sus archivos de posibles relaciones que los Procuradores enviaban a las Cortes, o las que presentaban a su vuelta.

La Encuesta, según Artola, fue dirigida a 15 juntas supremas, 7 audiencias, la Chancillería de Granada, 36 ayuntamientos, 39 obispados, 41 cabildos, 9 universidades, autoridades de Canarias y arzobispo de Toledo ${ }^{26}$. En el caso de los Ayuntamientos fueron:

Sevilla, Córdoba, Jaén, Granada, Cádiz, Badajoz, Cuenca, Ciudad Real, Valencia, Palma de Mallorca, Tarragona, Tortosa, Daroca, Calatayud, Balaguer, Albarracín, Barbastro, Teruel, Jaca, Huesca, Cervera, Borja, Lérida, Gerona, Murcia, Santiago, Co-

25 Artola, M. Los orígenes de la España Contemporánea. Madrid. CEPC, 2000, vol. I, pág. 306.

26 Además de la mencionada obra de ArTola, M. Los Orígenes..op. cit., vol. I, págs. 113-593, tengamos en cuenta: Arriazu, María Isabel. La Consulta de la Junta Central al País sobre Cortes. En: Estudios sobre las Cortes de Cádiz. Pamplona Universidad de Navarra, págs. 11-117. FernÁndeZ Martín, M. Derecho Parlamentario Español. Madrid. J. A. García 1885-1900, 3 volúmenes. Vol. I, págs. 436-623. INFORMES. Informes Oficiales sobre Cortes. Estudio preliminar de Federico Suárez Verdaguer, Pamplona, Universidad de Navarra, 1967-1974, 3 volúmenes. JiMÉnEZ DE GREGORIO, Fernando. La convocación a Cortes Constituyentes en 1810. Estado de la opinión española en punto a la reforma constitucional. $2^{a}$ ed. Barcelona, CSIC, 1955. LASARTE, Javier. La Consulta al País de 1809: un alegato contra la Hacienda del Antiguo Régimen. En: Economía y hacienda al final del Antiguo Régimen. Madrid. 1976, págs. 129-346. 
ruña, Betanzos, Tuy, Orense, Lugo, Mondoñedo, Oviedo, Málaga, Cartagena y La Carolina.

Las respuestas carecieron de homogeneidad, pero casi todas coincidían en la necesidad de una nueva división territorial más racional, manifestándose contra la pervivencia de la diversidad social característica del antiguo régimen, a favor de la supresión de fueros personales y territoriales, reduciendo todas las situaciones de privilegio al uniformismo igualitario. Se detecta la ausencia de un requerimiento concreto sobre la futura organización municipal, por lo que del conjunto de informes analizados en las sucesivas ediciones e interpretaciones, sólo 23 se refieren a las cuestiones municipales, en ellas encontramos la ausencia de sentimientos nostálgicos sobre el Municipio medieval, lo que contrastará con la recuperación de tales figuras desde perspectivas románticas a partir de mediados del siglo XIX.

Justificada son las peticiones del Ayuntamiento de Palma de Mallorca, para que los Municipios recobrasen sus antiguas funciones, en aquel momento mediatizados por las Audiencias, ya que en virtud de los Decretos de Nueva Planta habían perdido la mayoría de sus competencias tradicionales. Se detecta un deseo generalizado de que el Ayuntamiento surgido de la futura Constitución debía ser una institución nueva, sin vínculos con modelos pretéritos y dotados de una organización diferente.

La representatividad democrática de los Ayuntamientos también fue objeto de atención y reconocimiento por diversos consultados. Algunos se inclinaban por la posibilidad de que cualquier individuo pudiese acceder a los cargos, otros mantenían inequívocamente que los Ayuntamientos constituyesen la representación de cada vecindario respectivo, pero no se conseguirían resultados positivos sí se mantenían los procedimientos previstos en el Auto de 1766 para la elección del síndico o diputado del común, ya que a su amparo sólo concurrían los menos capaces $^{27}$. Para remediarlo se proponía un sistema de elección censitaria, con una escala de rentas a partir de los 100.000 reales para las capitales y pueblos de comercio, 40.000 en las cabezas de partido o corregimiento y 20.000 en los pueblos subalternos.

A la separación entre lo contencioso y lo gubernativo en el ámbito municipal, se refirieron, entre otros el Ayuntamiento de Palma de Mallorca, y la Audiencia de Galicia. ¿Hasta que punto tenían los consultados información del contenido del artículo 98 de la Constitución de Bayona? El Ayuntamiento de Palma, sensibilizado por el intervencionismo de la Audiencia, se mostró partidario de que

27 Serrano Belézar, M. Discurso... op. cit., págs. 190 y ss. recordemos a este respecto su opinión sobre las causas que provocaron la ineficacia del sistema. 
los tribunales sólo entendiesen de los asuntos de justicia «sin mezclarse en los de economía política, peculiar de los Ayuntamientos para cuyo fin se les forma a estos cuerpos». Más tajante era la respuesta de la Audiencia gallega al pedir la separación de la «administración del poder judicial» por el valor que tenía la propuesta de un alto órgano judicial, que debía entenderse como una clara petición de la separación de poderes. En el texto constitucional quedaron claramente definidos, al regular las funciones del alcalde, aunque la separación sólo resultase parcial, pues le encomendaron los juzgados de paz.

En la supresión de los señoríos jurisdiccionales, junto a la unificación de los fueros, coincidieron todos los opinantes, lo que no debe extrañar pues a fines del Antiguo Régimen los señoríos, además de afectar a la mitad de las instituciones territoriales españolas, eran de las tipologías más variadas y complejas ${ }^{28}$. Si a ello unimos la existencia de fueros civiles, militares y eclesiásticos tendremos un panorama aproximado de la confusión existente. Por eso mientras que por un lado, pedían la unificación de las jurisdicciones por medio de un solo fuero, lo que afectaría principalmente a la justicia, por otro se está cuestionando el sistema señorial en los Municipios, al coincidir en la propuesta para que todos los cargos locales fuesen por elección.

El complemento de la abolición del sistema señorial fue la amplia unanimidad concitada por el rechazo a una vieja corruptela: la venta de oficios, ya auspiciada desde el siglo XVIII por los Ilustrados y frustrada su reforma sucesivamente por la oposición de las oligarquías locales a desprenderse de sus privilegios y la imposibilidad de la Monarquía para adquirir lo que en su día enajenó, por lo que no resultó una sorpresa la oposición, casi unánime a la venta de oficios públicos, razón por la que los municipios y las jurisdicciones de muchos lugares de España habían pasado a dependencia señorial con todos los males que eso llevaba consigo.

El examen superficial de las respuestas a la Consulta al País, referidas a la organización municipal, nos hace llegar a la conclusión de que ésta no era una cuestión prioritaria para los españoles de 1809. Existía, eso sí, una crítica generalizada al sistema municipal del Antiguo Régimen, tanto por caduco como por ineficaz, las críticas se ampliaban a la enajenación de oficios y las corrupciones, que de tal práctica se derivaban, a la extinción de los señoríos, cuestiones, las dos últimas, que incidían en la democratización de las estructuras locales, pero que su importancia mayor estaba en que suponían la práctica liquidación del feudalismo y el alumbramiento de una nueva sociedad.

28 Principalmente en García Fernández, J. El origen... op. cit., pág. 225 y Tomás y VALIENTE, F. Manual... op. cit., págs. 408-410. 


\section{b) La abolición de los señoríos y el fin del feudalismo}

En este proceso de cambio institucional, se produjo un acontecimiento que marcó el futuro de España. y que debe entenderse como lo más próximo, aunque moderado, a las actitudes revolucionarias iniciadas en la Francia de 1789. Nos referimos al Decreto LXXXII de las Cortes Generales y extraordinarias de 9 de noviembre de 1811, sobre la incorporación de los señoríos jurisdiccionales a la Corona, por el que se prohibía la provisión de los corregimientos y alcaldías mayores de los lugares que fueron señorío. Factor muy interesante, pues aunque el debate del texto constitucional se encontraba avanzado por esa fecha, aún tardarían dos meses en llegar al estudio del Título IV, «Del Gobierno, interior de las provincias y los pueblos» ${ }^{29}$.

Con tal Decreto se trataba de interpretar el sentimiento casi generalizado contrario a la enajenación de oficios municipales, practicado habitualmente desde el siglo XVI y contra la que se habían manifestado desde entonces los ciudadanos, alcanzando por aquellos años de 1810 y 1811 gran asentimiento popular. La vinculación de oficios en las familias por juro de heredad, familias que en la mayor parte de los casos eran hidalgos, suponía que con esta compra tenían abierto el camino de acceso a la hidalguía, produciéndose de facto la señorialización de los municipios, que estaban en manos de una oligarquía, habiendo perdido desde hacía muchos años la fuerza democrática y autonómica, cuya memoria se perdía en la noche de los tiempos ${ }^{30}$.

El Decreto supuso la abolición del derecho de los señores jurisdiccionales a nombrar los oficios municipales y la unificación de todos los municipios en lo que se refiere a un sistema de provisión común. Sin dejar de reconocer su importancia, y aunque estamos ante un primer paso de la revolución burguesa al atacar los poderes jurisdiccionales y territoriales de la nobleza, no puede considerarse como una verdadera medida revolucionaria, pues no olvidemos que sólo

29 El debate del texto constitucional aún tardarían dos meses en llegar al estudio del Título IV, «Del Gobierno, interior de las provincias y los pueblos» referente a los Ayuntamientos y Diputaciones.

30 La quiebra del sistema señorial y su derogación en la obra legislativa de los doceañistas ha sido estudiado ampliamente. Sin olvidar los antecedentes del siglo XVIII, objeto de la atención de Sempere y Guarinos, J. Historia de los vínculos y Mayorazgos. Madrid. 1805, hemos de señalar los estudios de Moxó, Salvador. De incorporación de Señoríos a la Corona. Valladolid. 1959. Bernal (1977), Hernández Montalbán (1979), Clavero Salvador, Bartolomé. Propiedad feudal en Castilla (1369-1836). Madrid. 1989, Tomás y Valiente (1992), etc. Por otro lado los antecedentes de la abolición ya vimos que estaban en los propósitos antiseñoriales de José I y en los contenidos de la Consulta al País. 
afectó a los principios jurisdiccionales y no a la propiedad de la tierra, que resultó exenta de la medida para sus tenedores, lo que condicionó todo el futuro proceso de reforma de la Administración local ${ }^{31}$.

En el Decreto se produce una equiparación unitaria de los Municipios de señorío con los de realengo y se reconoce la forma de acceso a los cargos por elección, aunque sin determinar el procedimiento. En el contenido del Decreto que afecta a las cuestiones patrimoniales, se detecta un claro sentido de transación entre las posturas liberales y conservadoras, sobre todo en los artículos V y IX del Decreto que regulan el reconocimiento efectivo de los derechos patrimoniales, aunque en el artículo VII también se abolían la jurisdicción sobre molinos, aprovechamientos de aguas y montes quedando al libre uso de los pueblos, con arreglo al derecho común y a las reglas municipales establecidas en cada pueblo» ${ }^{32}$.

Desde la perspectiva municipalista, el Decreto mencionado supuso la abolición del derecho de los señores jurisdiccionales a nombrar todos los oficios municipales y la unificación de todos los municipios en lo que se refiere a un sistema de provisión común ${ }^{33}$. Ya hemos señalado el alcance de la medida, pues no podemos ignorar que casi la mitad de los municipios estaban supeditados a la jurisdicción señorial.

Al margen de otras consideraciones, hemos de referirnos a la tramitación del proyecto de Decreto de abolición, centrándonos en las referencias concretas y la incidencia de la extinción señorial en la futura Administración local española. Del seguimiento de los debates, entre las posturas liberales y las conservadoras, no parece apreciarse que en los doceañistas existiese una conciencia de la importancia e influencia en los Municipios de esta cuestión, recogida en dos artículos

II. Se procederá al nombramiento de todos los justicias y demás funcionarios públicos por el mismo orden y según se verifica en los pueblos de realengo.

III. Los Corregidores, alcaldes mayores y demás empleados comprendidos en el artículo anterior cesarán desde la publicación de este Decreto, a excepción de los Ayuntamientos y alcaldes ordinarios que permanecerán hasta fin del presente año.

Se produce una equiparación unitaria de los Municipios de señorío con los de realengo y se reconoce su forma de acceso a los cargos por elección, aunque sin determinar el procedimiento. En el contenido del Decreto que afecta a las cuestiones patrimoniales, se detecta un claro sentido de transación entre las posturas liberales y conservadoras, sobre todo en los artículos V y IX del Decreto que re-

31 García Fernández, J. El Origen..., op. cit., págs. 235 y 236.

32 Ibidem, pág. 241.

33 García Fernández, J. El Origen..., pág. 236. 
gulan el reconocimiento efectivo de los derechos patrimoniales, aunque en el artículo VII también se abolían la jurisdicción sobre molinos, aprovechamientos de aguas y montes quedando al libre uso de los pueblos, con arreglo al derecho común y a las reglas municipales establecidas en cada pueblo ${ }^{34}$.

En definitiva, García Fernández entiende que se dio un paso decisivo en la reestructuración política del Municipio al establecer un sistema electivo de los oficios municipales en más de la mitad de España, ante la posibilidad de retorno de ciertas competencias ${ }^{35}$. Percepción poco optimista, que se ve acentuada con la opinión de Morell, para el que se produce la sustitución del sistema feudal por otro de propietarios, pues el vínculo jurídico político queda en manos del Jefe político, gobernador, etc. pero la propiedad territorial sigue en manos de los antiguos señores, creando una clase de terratenientes a la que se incorporan a partir del segundo tercio de siglo los compradores de bienes desamortizados, entre los que también se encuentran individuos de la antigua nobleza. La situación condicionará el proceso democratizador de la Administración local española. Por eso dice Morell que sí el Municipio del Antiguo Régimen estaba en manos de una minoría oligárquica, en la práctica las reformas del siglo XIX, no supusieron cambios significativos ${ }^{36}$.

Nos encontramos, una vez más, con un falseamiento de la voluntad política democratizadora, que buscará todos los resquicios para defender los intereses económicos y que en el futuro actuará con los reconocimientos constitucionales Cierto que resultaba insostenible mantener los dos principios básicos del feudalismo: identificación de la jurisdicción con la propiedad de la tierra. Pero si había que ceder, que fuese en lo primero, salvaguardando por encima de todo el factor económico agrario. Desde esta perspectiva era imposible que la defensa a ultranza de estos derechos, no propiciase la implantación de un sistema caciquil, que distorsionó la actividad de la Administración local española durante más de un siglo.

En definitiva, en la administración local española moderna vamos a encontrar junto a una clara influencia de la tradición municipalista medieval castellana, basada en las libertades y la autonomía local, indudablemente sobrevalorada y

34 García Fernández, J. El Origen..., pág. 241.

35 Ibidem, pág. 243. "Porque en el compromiso político que da lugar a la promulgación del Decreto se adoptó una medida conciliadora que en la práctica legalizó los continuos latrocinios que los señores jurisdiccionales habian infligido a los en sus bienes, con lo que el arranque del régimen constitucional se produjo en condiciones patrimoniales de debilidad, con la consiguiente consecuencia de mantener la propiedad agraria en manos de la nobleza terrateniente, a diferencia de Francia, donde la venta de bienes nacionales creó una poderosa burguesía agraria.

36 Morell OCaña, Luis.: El Régimen Local español. Madrid. Cívitas. 1988, vol. I, pág. 99. 
exaltadas, un importante componente de inspiración francesa que analizó García de Enterría, en el sentido de que se sustituye el orden estamental por «el principio de un orden social nuevo, de territorialidad de los derechos sociales y de borizontalidad uniforme en su distribución» ${ }^{37}$.

\section{c) Los Ayuntamientos en la tramitación del Proyecto de Constitución de 1812}

La génesis del proyecto constitucional de 1812 se estableció a partir de la Comisión de su nombre, que inauguró una tradición en el parlamentarismo español mantenida hasta la actualidad ${ }^{38}$. La Comisión nació a propuesta del diputado Oliveros, que fue aprobada en la sesión del nueve de diciembre de 1810, disponiendo: "que se nombre una Comisión de ocho individuos, cuando menos, para que teniendo presente los trabajos preparados por la Junta Central proponga un proyecto de Constitución política de la Monarquía» ${ }^{39}$.

Por lo general las actas de la Comisión son excesivamente escuetas, pues en muchas ocasiones sólo figuran los acuerdos adoptados, aunque a veces hubo excepciones, en los que se especifican algunos detalles que dan idea de una importante discusión, y de la existencia de una «fracción», poco conocida en su origen e ideología, no vinculada a los diputados americanos, pero que desempeñó un importante papel. En lo que se refiere a Municipios y Provincias, al parecer, no se actuó sobre un texto previo, sino que hubo sugerencias de diversos grupos, principalmente los diputados americanos, y poco más pues las actas son escuetas y algunos artículos se aprobaron sin discusión ${ }^{40}$.

La Comisión discutió a partir del 6 de noviembre de 1811 el título correspondiente al Gobierno interior de las provincias y de los pueblos. El tema central de las dos primeras reuniones fue la creación de ayuntamientos donde no los hubiese, propuesta realizada por los diputados americanos en función de las grandes distancias y extensiones de aquellos territorios, propuesta que revistió una gran importancia y que ha pasado tradicionalmente desapercibida, pese a su transcendencia. En esta ocasión existió un debate más amplio en el que se discutieron

37 García de Enterría, E.: «Turgot y los orígenes del municipalismo moderno». Madrid. Revista de Administración Pública. núm. 33, 1960, pág. 86.

38 Suarez Verdaguer, F.: «El proceso de convocatoria a Cortes (1809-1810)». Pamplona. Eunsa. 1982. Idem. las Cortes de Cádiz. Madrid. Rialp. 1982. MARTinez MARINA, F.:« Teoría de las Cortes», Madrid. Editoria nacional. 3 vols. 1976.

39 Diario de Sesiones de las Cortes (En lo sucesivo DSC) Sesión de 9 de diciembre de 1810).

40 Orduña Rebollo, E.: Municipios y Provincias... op. cit., pág. 291. 
diversas cuestiones como la determinación del número de concejales, la instalación de Ayuntamientos donde no los hubiese, a quien correspondía la iniciativa de su establecimiento, etc. ${ }^{41}$.

Las actas son más explícitas en estas sesiones y recogen los acuerdos sobre las cuestiones debatidas, transformándolos en los artículos 310, 311 y 312 del texto constitucional definitivo y que comprendían los siguientes extremos:

I. Habría Ayuntamientos en todos los pueblos que ya existiesen o donde conviniese instalarlos, siempre que en el pueblo o en su comarca se llegase a mil almas.

II. La Ley determinará el número de individuos que formarán los Ayuntamientos

III. Alcaldes, regidores y procuradores sindicos se elegirán por los pueblos.

IV. Cesarán los regidores perpetuos, sea cual sea su título.

Además la Comisión acordó, a consecuencia de «la ley ya hecha que quita a los señores territoriales la nominación de estos cargos», y ante lo novedoso del tema, elaborar una ley electoral para todo el reino, que determinase el número de electos en función de la población de cada municipio y otros detalles relacionados con el asunto. Acordando también, que las Diputaciones provinciales serían las encargadas de establecer Ayuntamientos en los lugares donde no existiesen y fuese conveniente establecerlos ${ }^{42}$.

En los artículos siguientes, 313 a 320, se vuelve a la sobriedad en el contenido de las Actas, según las cuales fueron aprobadas sin controversias, y así se mantendrían prácticamente en el texto Constitucional cuestiones tan importantes como la elección directa de los cargos municipales, elección anual de alcalde y bianual de regidores y procuradores síndicos, requisitos de los electores, incompatibilidades, obligación del cargo, existencia de un secretario en cada Ayuntamiento, etc.

En el conjunto del texto constitucional hemos de hacer abstración de lo referente al Municipio, porque si en otras muchas cuestiones cualquiera de los supuestos podría ser válido, en ésta parece que no se trabajó sobre un texto previo, sino que además de las aportaciones de la Comisión resultaron de gran importancia las sugerencias de la denominada fracción; desde luego en este Título, la influencia de los diputados americanos fue decisiva, pero existen muchas dudas y pocas luces en la documentación existente, por lo que el rigor puede resentirse y dejar muchas preguntas sin respuesta.

En esta ocasión surge la posible duda sobre la existencia de un acuerdo entre liberales y conservadores sobre un texto en el contenido municipal más próximo

41 Actas de la Comision de Constitucion. Sesión del 12 de noviembre de 1811.

${ }^{42}$ Idem. Sesión del día 13 de noviembre de 1811. 
a las tradiciones españolas, reiterado por Argüelles y manifestado en el Discurso preliminar, cuando por el contrario el proyecto sometido a las Cortes por la Comisión rompía con muchas formas de la organización municipal del Antiguo Régimen.

\section{d) Los Ayuntamientos en el texto constitucional}

En los debates constitucionales sobre el Municipio, pese a tratarse de un tema que posteriormente se consideró de gran importancia para la organización territorial del Estado, no participó gran número de diputados. Un recuento del Diario de Sesiones, recogido por Rafael Comenge nos permite conocer su profesión, origen y número, que asciende a cuarenta y uno, a los que se deben añadir otros siete diputados que no intervinieron en los debates, pero aportaron diversas proposiciones. Su origen geográfico resulta de interés, pues no sólo se ratifica la implicación firme y decidida de los diputados americanos, pese a la situación que se vivía en sus lugares de origen, sino por la importancia de sus intervenciones y su clara actitud en defensa de fórmulas descentralizadoras. Por tal razón consideramos oportuno incluir la nómina por orden de intervención de todos ellos:

Diputados Peninsulares e Islas Adyacentes

El conde de Toreno (Asturias)

Joaquín Díaz Caneja Abogado de los Reales Consejos (León)

Isidoro Martínez Fortún (Murcia)

José Antonio Mombiela. Decano del Colegio de Abogados (Valencia)

Felipe Aner de Esteban. Abogado (Cataluña)

Diego Muñoz Torrero Chantre de Villafranca del Bierzo (Extremadura)

Agustín de Argüelles. (Asturias)

Bernardo Martínez (Orense)

José Martínez García. Auditor general (Valencia)

Juan de Lera y Cano (La Mancha)

Manuel A. García Herreros. Doctor Universidad de Alcalá (Soria suplente)

Mariano Garoz y Peñalver. Oficial Secretaría de Estado (La Mancha suplente)

Francisco Gómez Fernández (Sevilla)

Manuel Luxán Relator del Consejo de Castilla. (Extremadura)

El Marqués de Villafranca. Teniente general (Murcia)

Antonio Oliveros. Canónigo de Madrid (Extremadura)

José Espiga. Caballero de la Orden de Carlos III (Cataluña) 
José Zorraquín. Relator del Consejo de Castilla (Madrid suplente)

Lázaro Dou y Bassols Catedrático de Decreto Universidad de Cervera (Cataluña)

Francisco J. Borrul y Vilanova Juez de diezmos (Valencia)

José Alonso López. Comisario Inspección Gral. Caminos (Galicia)

Evaristo Pérez de Castro Oficial mayor $2^{\circ}$ Secretaría de Estado (Valladolid sup.)

El obispo de Calaborra (Burgos)

Pedro Gordillo. Rector de la Iglesia del Sagrario (Canarias)

Jaime Creus. Canónigo de Urgel (Cataluña)

Agustín Rodríguez Baamonde. Abogado de los Reales Consejos (Tuy)

Santiago Key y Muñoz. Presbitero (Canarias)

Guillermo Moraguas (Mallorca)

Proponentes

Gregorio Laguna. Mariscal de campo (Extremadura)

Alfonso María de Torres. Marqués de San Miguel de Cruz. (Cádiz)

Diputados Americanos

Florencio del Castillo. Presbitero. (Cartago, Costa Rica)

José Miguel Ramos de Arispe (Coabuila. América Septentrional)

Antonio de Larrazábal y Arivillaga, Canónigo (Santiago de los Caballeros)

Blas Ostolaza. Presbitero (Perú)

Vicente Morales de Duádez. Alcalde de Corte de la Audiencia de Lima (Perú)

José Simón de Uría. Canónigo (Guadalajara)

José Cayetano Foncerrada. Canónigo (Valladolid de Michoacán)

Joaquín Fernández de Leyva. Alcalde Audiencia de Lima (Chile suplente)

Andrés de Jaúregui (La Habana)

José M. Guridi y Alcocer. Párroco de Tacubayán (Tlascala. Nueva España)

José Antonio López de la Plata. Abogado (Santiago de León. Nicaragua)

José Ignacio Avila (San Salvador)

Proponentes

José Miguel Gordón. Catedrático Seminario Guadalajara (Zacatecas) Joaquín Maniau. Comisario de los Reales Ejércitos (Veracruz) 
Aunque ampliamente estudiado, recordemos que la Administración local figuraba en el proyecto con el Título IV y en el texto definitivo con el VI, bajo el epígrafe «Del gobierno interior de las provincias y de los pueblos» ${ }^{43}$. Se iniciaron los debates del capítulo I correspondiente al Municipio, con el artículo 307 (309 definitivo) en la sesión del día 10 de enero de 1812, que pasó desapercibida, continuando el 11 . Los días 12 y 13 se dedicaron al capítulo II relativo a las Diputaciones Provinciales y el 14 volvió a debatirse el tema del Municipio al haber presentado los diputados americanos varias propuestas sobre artículos ya aprobados. Señalar que en los debates sobre el Municipio, pese a su importancia para la futura organización territorial del Estado, no participaron gran número de diputados ${ }^{44}$.

En la discusión del artículo 307 (309 definitivo) intervinieron los señores Castillo, Toreno, Arispe, Isidoro Martínez y Mombiela. El primero pidió en aras de la autonomía municipal y ante el temor de una permanente intromisión del poder central en el municipio, se prohibiese «que los jefes políticos presidan los cabildos» y que lo hiciesen exclusivamente «los alcaldes o regidor más antiguo» ${ }^{45}$. Oponiéndose el Conde de Toreno, afirmando que el diputado Castillo estaba equivocado al pensar que los ayuntamientos eran representantes de los pueblos por quienes eran nombrados, lo que era según su criterio un error, pues « en la Nación no hay más representación que la del Congreso Nacional», porque en caso contrario «tendríamos que los ayuntamientos siendo una representación, y existiendo consiguientemente como cuerpos separados, formarian una nación federada», y termina calificando a los ayuntamientos exclusivamente como «unos agentes del poder ejecuti-

43 Una aproximación bibliográfica en: CASTRO, C.: La revolución liberal y los Municipios españoles. Madrid. Alianza. 1979. Gallego Anabitarte, A.: «Notas histórico-juridícas sobre régimen local español (intento de revisión)», en: Actas del II Symposium de Historia de la Administración. Madrid. IEA. 1971. GARCÍA DE ENTERriA, E.: «La formación histórica del principio de autotutela en la Administración», Madrid, Moneda y Crédito, 128, 1974, págs. 59-87. GARCÍA FERnÁNDEZ, J.: «El origen del Municipio Constitucional», Madrid, IEAL, 1983. Martín Mateo, R. y Orduña ReboLLO, E.: «La perspectiva histórica de la cuestión municipal en las diversas Constituciones españolas», Madrid. ICE, núm. 549, 1979. Martin Retortillo, S. y Argullol, E.: «Aproximación histórica al tema de la descentralización 1812-1931», en: Descentralización Administrativa. Madrid. Alfaguara, 1973, vol. I. Orduña Rebollo, E.: «Constitución y Ayuntamientos en 1812», en: Materiales para el estudio de la Constitución de 1812, Madrid. Tecnos. 1989. PAREJO ALFONSO, L.: «La regón y la legislación histórica de régimen local», en: Las Autonomías Regionales. Madrid. Instituto Nacional de Prospectiva, 1977. POSADA, A.: «Evolución legislativa del régimen local en España. 1812-1909», $2^{a}$ ed., Madrid, IEAL, 1982.

44 Una revisión del Diario de Sesiones nos permite conocer el número de participantes: 41 diputados, en su origen geográfico existió una preponderancia de americanos: 12.

45 Diario de las discusiones y actas de las Cortes... sesión de 10 de enero de 1812, pág. 210. 
vo para el gobierno económico de los pueblos. pero se prefiere que estos agentes sean escogidos por sus propios vecinos...». Esta idea de subordinación la reitera posteriormente de forma categórica al afirmar que:

"los ayuntamientos son esencialmente subalternos del poder ejecutivo; de manera, que sólo son un instrumente de éste (...) pero al mismo tiempo, para alejar que no se deslicen y propendan insensiblemente al federalismo, como es su natural tendencia, se hace necesario ponerles el freno del jefe politico (...) para que los tenga a raya y conserve la unidad de acción en las medidas de gobierno ${ }^{46}$."

Toreno establecía la función administrativamente subordinada del Municipio a favor de la representación nacional que debía ser única, lo que configuró la existencia de un ejecutivo muy fuerte que llegase a todos los confines de la nación por medio de los jefes políticos y de los órganos subalternos, como califica a los Ayuntamientos. Por tanto dicha subordinación se producía por medio de la relación jerárquica entre el Jefe político como funcionario del Gobierno y su subordinado el Alcalde, entre la Diputación Provincial y el Ayuntamiento. El Jefe político actúa como agente central, que incluso preside el Municipio donde reside (recuérdese la dualidad del Antiguo Régimen por la que el Intendente acumulaba el oficio de Corregidor en la capital de la provincia). En cuanto a la Diputación, también presidida por el Jefe político, actuaba como organismo del Estado y no como un ente local. Se cierra al proceso de subordinación con las técnicas de tutela y control ${ }^{47}$.

El diputado americano Arispe señaló el problema que se producía, en ocasiones, por ausencia o capricho del jefe político frustrándose las reuniones del Ayuntamiento. Por ello pedía que tuviese afectividad la sustitución por el Alcalde o el regidor más antiguo. Sobre lo mismo reiteraron sus opiniones los señores Caneja y Martínez, advirtiendo que el texto del proyecto recogía fielmente tal posibilidad sustitutoria. Por último, intervendría Mombiela, el cual pedía incluir en la composición del Ayuntamiento no sólo al síndico procurador, sino también al síndico personero, figura, como es sabido, prevista por Carlos III en 1766 cuando introdujo las mencionadas reformas en la Administración local. Finalmente el artículo fue aprobado según el proyecto sin introducir modificaciones.

El artículo siguiente 308 del proyecto, 310 del texto constitucional, a los efectos de nuestro trabajo, es otro de los más importantes. Se trataba de la previsión de instituir Ayuntamientos en los pueblos que no los hubiere y resultase

46 Ibidem, pág. 211.

47 Parejo Alfonso, Luciano, Derecho básico... op. cit., pág. 31. 
conveniente su existencia, siendo, en todo caso, obligatorio a partir de las mil almas, bien en el pueblo, bien en su comarca. Y aquí nos encontramos con otro problema resuelto recientemente: la ignorancia sobre el número de Ayuntamientos existentes a partir de la Constitución de 1812 y en sus años inmediatos sobre todo en el trienio liberal, hasta el censo de 1842 no ha podido ser establecido tal dato ya no sólo con rigor, sino con aproximación ${ }^{48}$.

En su discusión, también el 10 de enero, participaros los diputados Aner, Muñoz Torrero, Isidoro Martínez, Argüelles, Bernardo Martínez, Arispe, Lera y García Herreros. En un principio, según se deduce de la lectura de las actas, el artículo fue incluido a propuesta de los diputados americanos por los problemas de distancias de aquellas tierras y la obligación de largos desplazamientos a la sede del cabildo o concejo para resolver cualquier asunto. Tal cuestión también sería alegada por los diputados peninsulares, abundando en las mismas razones.

En general, los diputados eran partidarios de la implantación de Ayuntamientos en todos los pueblos, incluso con menos de 1.000 habitantes. El Sr. Aner recordaba que «las leyes llaman pueblo al que tenga 26 o 27 familias» (calculaban a cuatro miembros cada unidad familiar), por lo tanto, era preciso no poner cortapisas a la creación de Ayuntamientos. Dos eran las dificultades que señalaron varios diputados: primero, la falta de medios económicos para que los pueblos con menos de mil habitantes pudiesen mantener lo que en términos de nuestros días llamaríamos «servicios mínimos», entre los que figuraba la retribución al escribano, limpieza, aseo del pueblo, etc.

Y segundo, los problemas que se plantearían con los términos municipales, pues al crear nuevos Ayuntamientos se fraccionaban términos pertenecientes a los pueblos mayores, e incluso de las capitales, produciendo los consiguientes perjuicios y resistencias a tal situación, así como el caso de pueblos edificados en terrenos particulares. Contestó Argüelles en nombre de la ponencia, exponiendo que no eran lo mismo los Ayuntamientos elegidos previstos en el texto constitucional, con los que habían existido hasta entonces compuestos por miembros de juro de heredad. Los nuevos Ayuntamientos defenderían la prosperidad de sus pueblos y los sacrificios momentáneos que tuviesen que hacer se verían compensados por los beneficios y sobre todo por la utilidad que obtendrían en el futuro.

Otra posibilidad era la de mantener el término, pero dividir las jurisdicciones, situación que no era admisible y sería rechazada. En definitiva, salvando las dudas sobre la supervivencia económica del Ayuntamiento y las dificultades a la

48 Orduña Rebollo, E.: «Nuevas aportaciones sobre el mapa municipal español», Madrid. REAL, núm. 291, enero-abril 2003, págs. 779-826. 
hora de adjudicar términos, pues forzosamente habría de ser a expensas de otro existente, la opinión mayoritaria era favorable a la creación y extensión de Ayuntamientos lo que finalmente supondría que el artículo fuese aprobado en su versión original.

Contestó Argüelles en nombre de la ponencia, exponiendo que no eran lo mismo los Ayuntamientos elegidos previstos en el texto constitucional, con los que habían existido hasta entonces compuestos por miembros de juro de heredad. Otra posibilidad era la de mantener el término, pero dividir las jurisdicciones, situación que fue rechazada. En definitiva, salvando las dudas sobre la supervivencia económica del Ayuntamiento y las dificultades a la hora de adjudicar términos, pues forzosamente habría de ser a expensas de otro existente, la opinión mayoritaria era favorable a la creación y extensión de Ayuntamientos lo que finalmente supuso que el artículo fuese aprobado en su versión original.

El artículo 309 fue aprobado sin discusión. En los debates del 310 (312 definitivo), que determinaba la elección de «los alcaldes, regidores y procuradores síndicos en los pueblos» y el cese de los «regidores y demás que sirvan oficios perpetuos en los ayuntamientos, cualquiera que sea su título y denominación». Intervinieron los diputados Larrazábal, Toreno, Ostolza, Gómez Fernández, Argüelles, Luján y Villafranca. Se trataba de un precepto básico para acabar con uno de los abusos más notorios de la sociedad estamental: la venta de oficios. Este artículo, reflejo del mencionado Decreto LXXXII de 6 de agosto de 1811, fue el que significó la mayor ruptura con el antiguo régimen, al menos en el ámbito de la moderna Administración local, asimilando los principios de igualdad y unidad.

En el debate los diputados se mostraron fervientes partidarios de acabar con aquella situación, hasta el extremo de que los que tenían algún título de regidor perpetuo renunciaron allí mismo a sus privilegios sin condiciones. En este sentido fue ejemplar la actitud y renuncia del conde de Toreno. En el mismo sentido se manifestó el Sr. Luján, el cual tenía dos títulos de regidor perpetuo y renunció a ellos sin exigir «remuneración ni recompensa alguna». El Sr. Larrazábal, defendió en aras de la continuidad municipal la supervivencia de una tercera parte de los regidores perpetuos en los Ayuntamientos, al que respondió el Conde de Toreno, considerando superflua la propuesta pues los regidores se mudarían por mitades cada año, y Argüelles hizo causa común, ya que él había tenido «la fortuna de baber nacido en un pueblo en que estos oficios son redimibles desde el escribano basta el juez». Finalmente el problema de la abstención electoral fue abordado por el Marqués de Villafranca, con la propuesta de que el voto fuese obligatorio. El artículo se aprobó en los mismos términos que constaba en el proyecto.

La figura del alcalde fue debatida en los capítulos II y III del Título VI, referidos al poder judicial, donde se establecieron las diferencias y delimitaciones 
entre lo contencioso y lo gubernativo. En las discusiones del Título V (artículos 311 en el que intervinieron Ramos de Arispe, Larrazábal, Mendiola, Oliveros y Morales Suáez), casi no aparecen referencias a la posición del alcalde en el Ayuntamiento. Como señala García Fernández, al haberse producido la desjudialización del alcalde, su figura quedó fuera del interés de los diputados durante el debate constitucional, quizá porque de acuerdo con lo expuesto por Toreno y Argüielles, se suponía que el alcalde sería la cabeza del órgano subordinado, en este caso el Ayuntamiento ${ }^{49}$.

Aquí podemos encontrar algunas reminiscencias del Antiguo Régimen, pues a pesar de la separación de las competencias judiciales y gubernativas del Alcalde vistas anteriormente, no podemos ignorar su carácter híbrido señalado por Santamaría Pastor ${ }^{50}$. Aunque se enmarca formalmente en las funciones gubernativas, aún conserva residuos judiciales, a pesar de ser actuaciones meramente conciliatorias, quedando jerarquizado al poder ejecutivo a través del Jefe político ${ }^{51}$.

En este marco de subordinación al Gobierno, el alcalde asume la función de jefe de la Milicia nacional, integrada por ciudadanos convocados por el mismo y financiados por el Ayuntamiento. Ostentando también la jefatura militar del municipio en ausencia de la autoridad militar, lo que definirá Morell como ejercicio de la jefatura de efectivos armados y de funciones jurisdiccionales al referirse a su actuación como juez de $\mathrm{paz}^{52}$. Las funciones militares del Alcalde serán sustituidas a mediados del siglo XIX por las de delegado gubernativo, condición que no perderá hasta hace pocos años.

La elección de Alcaldes (artículo 312 y 313 en los que intervinieron los señores Aner, Dou y Borrul) se regulaba por un procedimiento indirecto. El artículo 314 (316 definitivo) se aprobó sin discusión. Los alcaldes, regidores y procuradores síndicos eran renovables cada año, entre los ciudadanos en el ejercicio de sus derechos, mayores de veinticinco años, con cinco de vecindad, según consta en el artículo 315 (317 definitivo). Los artículos 316, 317 y 318, (correspondientes a los definitivos 318, 319 y 320) fueron aprobados sin discusión.

Las competencias municipales se regulaban en el artículo 319 (321 definitivo) a través de nueve apartados, donde se describían las propias del Ayuntamiento. Pero de nuevo sorprende que tal cuestión no motivase debates signifi-

49 García Fernández, J., El Origen... op. cit., pág. 271.

50 Santamaría Pastor, J. A., Sobre la génesis del Derecho Español en el siglos XIX (18121854), Sevilla. Instituto García Oviedo, 1973, pág. 32.

51 Parejo Alfonso, L., Derecho básico... op. cit., pág. 32.

52 Morell Ocaña, L., El Régimen local... op. cit., pág. 540. 
cativos, salvo en algún apartado concreto, pese a su relación con el concepto revolucionario francés del pouvoir municipal. En tal sentido los párrafos $1^{\circ}$ policía sanitaria, $2^{\circ}$ seguridad y orden público, $3^{\circ}$ administración de propios y arbitrios, $4^{\circ}$ repartimiento y contribuciones, $7^{\circ}$ obras públicas municipales, y $9^{\circ}$ fomento, se aprobaron sin ningún debate según la propuesta de la Comisión.

El párrafo $5^{\circ}$ escuelas y el $6^{\circ}$ hospitales provocaron alguna discusión de más entidad, en la que intervinieron los diputados García Herreros, Pérez de Castro, el Obispo de Calahorra, Oliveros, Gordillo, Espiga y Argüelles. Aunque en el caso de las escuelas el debate surgió después de aprobado el párrafo al plantear García Herreros, diputado de Soria, una duda acerca de si en este precepto se excluían del cuidado municipal las escuelas y centros docentes privados. La polémica se planteó al defender Pérez de Castro y el obispo de Calahorra el principio de que el Municipio sólo debía cuidar los establecimientos sufragados por el común, mientras que Oliveros, sacerdote extremeño mantenía que el Ayuntamiento debía ejercer la inspección de todos los establecimientos, públicos o privados, lo que dio lugar a una intervención de Argüelles que puso punto final a la cuestión, atribuyendo la inspección pública al Gobierno para todos los establecimientos docentes, mientras que la dirección de los centros particulares correspondía a los fundadores.

Respecto al apartado $6^{\circ}$, también se suscitó una cuestión colateral sobre la posibilidad de que el precepto perjudicaría al obispo de Guadalajara de Méjico por la pérdida de sus derechos de patronato sobre la Casa de Misericordia. Aunque la mayoría evitó la confrontación remitiéndose a normas posteriores, Lázaro Dou y Bassols, apoyado por el mejicano Foncerrada y el catalán Creus entendían que podía perjudicar el derecho de propiedad. Más radical el peruano Leyva advirtió posibles ingerencias eclesiásticas, por lo que se pasó a votación sin otras intervenciones, siendo aprobado el texto original.

El párrafo $8^{\circ}$, correspondiente a las ordenanzas, fue también aprobado sin discusión, como consta en el Diario, por lo que las razones de que fuesen las Cortes el órgano competente para la aprobación de las Ordenanzas no resulta conocido, pero dos días después el peruano Leyva, en el curso del debate del artículo 324 (326 definitivo) sobre las posibles tendencias federalistas frente a la unidad de la representación nacional y el papel subordinado de los Ayuntamientos, advierte que con motivo de atribuir a las Cortes la aprobación de las Ordenanzas, prevista en el artículo $321.8^{\circ}$, se había establecido un control parlamentario que evitaba el supuesto riesgo de federalismo. Ahora bien tan significativo procedimiento de aprobación de las Ordenanzas municipales por las Cortes no quiere decir que se produzca una ruptura con el sistema determinado por la Constitución de encuadramiento en el poder ejecutivo y subordinado a él. Lo cierto es que 
en este asunto se sustituyó al Consejo de Castilla del Antiguo Régimen por las Cortes del Estado constitucional. Los artículos 320 y 321 (322 y 323 definitivos) serían aprobados sin debate en la sesión del 12 de enero de 1812.

\section{e) El efímero desarrollo constitucional de la legislación de los Ayuntamientos}

El desarrollo normativo municipal de la Constitución de 1812 se realizó a través del Decreto de 23 de mayo del mismo año por el que se ordenaba la formación de los Ayuntamientos constitucionales. A lo largo de estos meses nos vamos a encontrar con las dificultades propias de un cambio y una verdadera transición política, pero también vamos a contemplar la pervivencia de instituciones del Antiguo Régimen que aún tardarán algunos años en transformarse o desaparecer.

Disponía el Decreto la creación de Ayuntamientos en aquellos lugares de población inferior a las mil almas y cuyas circunstancias particulares, agrícolas o industriales lo aconsejasen. Simultáneamente disponía el cese de todos los regidores y demás oficios perpetuos de los Ayuntamientos previendo la ocupación de vacantes mediante elección. También determinaba la proporción de regidores en función de la población, fijando como tope mínimo para las capitales de provincia el número de doce.

No debemos pensar que los preceptos de la Constitución fueron imponiéndose idílicamente, máxime en tema tan conflictivo como el de los Ayuntamientos. Una revisión a la Colección de Decretos de las Cortes Generales y Extraordinarias es por demás ilustrativa. Tempranamente, el 10 de julio de 1812, se promulga el Decreto CLXXIX referente a «Reglas sobre la formación de los ayuntamientos constitucionales», que en realidad es una aclaración al Decreto de 23 de mayo de 1812 anteriormente citado. Se reitera el cese de todos los regidores perpetuos y de todos los «individuos que actualmente componen dichos cuerpos», aunque no se les impedía presentarse a la elección. La elección de secretario del Ayuntamiento podía no recaer en un escribano y las juntas de sanidad continuarían desempeñando las funciones que ejercían, hasta que la Regencia, de acuerdo con los Ayuntamientos, formalizase por el Ministerio de la Gobernación, la normativa que regulase tales funciones, que serían aprobadas por las Cortes.

La costumbre y la práctica generalmente observada, así como las leyes canónicas, los fueros particulares y las mismas ordenanzas municipales, excluían a los eclesiásticos para ejercer los oficios del concejo; por ello las Cortes decretaron que los clérigos seculares no podían ser nombrados ni elegidos para ningún oficio del Ayuntamiento ni concejo, pero, sin embargo, de acuerdo con el nuevo espíritu 
democrático, a todos aquellos que estuviesen en el ejercicio de los derechos de ciudadano, se les reconocía el derecho al voto en las elecciones constitucionales.

Otro problema que surgió con frecuencia era el del ejercicio de la justicia por los alcaldes constitucionales. Tales funciones sólo se reconocieron por el Decreto de 7 de octubre a los alcaldes constitucionales de los pueblos de señorío «que antes eran pedáneos», para que ejercieran la jurisdicción ordinaria civil y criminal en el término jurisdiccional o territorio que anteriormente tenían señalado.

Los reiterados incidentes motivaron una nueva Orden el 8 de noviembre, por la que se disponía que los comisionados para publicar la constitución y formar el Ayuntamiento constitucional en los pueblos que fueron de señorío, se retirasen concluida su comisión, sin ejercer ninguna jurisdicción, con el objeto de que los alcaldes y corporaciones constitucionales desempeñasen sus respectivas funciones.

En el caso de Galicia surgieron diversos conflictos en la formación de varios Ayuntamientos, lo que motivó la Orden de las Cortes de 18 de febrero de 1813, reprobando la Orden del jefe político (el marqués de Campo Sagrado) quien retrasó la formación de 55 Ayuntamientos en pueblos que los tenían antes y prohibió a los pueblos que tenían mil almas que formasen el suyo, mientras no se instalase la Diputación Provincial. Sin embargo ratificaba otra Orden del mencionado jefe político que preveía la capitalidad del Ayuntamiento en el lugar que fuese más conveniente y proporcionado al interés de los pueblos; no obstante esta disposición «debe entenderse sin perjuicio del artículo 310 de la Constitución». Finalmente, recordaba que ningún jefe político podía estorbar a los pueblos la formación de sus Ayuntamientos, a menos que le constase carecían de la población requerida por la Constitución, por lo que tenían que esperar a la instalación de la Diputación Provincial.

La extinción de los oficios perpetuos o de otro tipo, existentes en los antiguos Ayuntamientos, no supuso una ruptura desairada contra los que ostentaban tales títulos. Por el contrario, el Decreto de las Cortes Generales de 24 de marzo de 1813 dispuso que «los regidores y demás individuos de los ayuntamientos fieles de las Españas en toda la Monarquía, conservaran los honores, tratamiento y uso de uniforme...», lo que en definitiva suponía una mera distinción protocolaria pero ninguna función ejecutiva.

Finalmente, se promulgó el Decreto de 11 de agosto de 1813 que fijaba varias reglas para el gobierno de las Diputaciones y Ayuntamientos. Destacando en lo que afecta a estos últimos, la prohibición de que ningún vocal del Ayuntamiento pudiese nombrar sustituto, regulando en la regla $2^{\mathrm{a}}$ el orden de suplencias entre los alcaldes y regidores. También se declara la incompatibilidad en el ejercicio de los cargos concejiles con el de diputado a Cortes o miembro de la Diputación Provincial, aunque no existe impedimento de pasar a uno u otro cargo, 
pero siempre abandonando el anterior. La ausencia de electores para los cargos concejiles, siempre que no existiese mayoría, se resolvían mediante la formación de «juntas de parroquia» y se suprimían los sueldos que disfrutaban algunos cargos, siendo en lo sucesivo gratuitos y sin emolumento alguno su desempeño.

Hasta aquí la normativa que existió en materia municipal desde la promulgación de la Constitución de 1812, período que realmente se inició con el Decreto de 23 de mayo de 1812 y se cerró con la Instrucción para el gobierno económico-político de las provincias de 23 de junio de 1813 . En poco más de un año se dictaron unas normas «tipo puente» diríamos ahora, que renovaron la Administración municipal. Aunque al analizarlas con cierto detalle comprobamos que su propósito, fundamentalmente, estaba presidido por dos objetivos: la creación e instalación de Ayuntamientos constitucionales y la elección de los cargos. Junto a ello habrá una serie de cuestiones sobre procedimiento y funcionamiento que van recorriendo el camino de la normalización constitucional de los Ayuntamientos, entre las que señalaríamos, las incompatibilidades, proscripción de retribuciones, conflictos con los comisionados, cuestiones de competencias, etc., problemas en definitiva típicos de una administración que inicia su andadura.

El texto normativo que influyó decisivamente en el período constitucional, al menos hasta la promulgación de la Ley Municipal de 1823, fue el Decreto CCLXIX de 23 de junio de 1813, que aprobaba la «Instrucción para el gobierno económico-político de las provincias», estaba articulado en tres capítulos: I, De las obligaciones de los Ayuntamientos, II De las obligaciones y cargos de las Diputaciones Provinciales y III De los Jefes políticos; como se puede percibir por el enunciado de los títulos, en los que se reitera el concepto obligaciones, poco se puede dudar de los condicionamientos de su contenido ni que se trataba de un extenso desarrollo del artículo 321 de la Constitución, así como la determinación de algunos aspectos de los siguientes artículos 322 y 323 del texto constitucional.

Las competencias atribuidas a los Ayuntamientos por la Instrucción de 23 de junio de 1813 son de dos tipos. Por un lado, las comprendidas en el artículo 321 de la Constitución, que tienen un ámbito doméstico, de propias y que se enmarcan en el principio de autogobierno municipal:

$1^{\circ}$ la policía de salubridad y comodidad;

$2^{\circ}$ el auxilio de alcalde en cuanto a la seguridad de las personas y bienes de los vecinos y a la conservación del orden público;

$3^{\circ}$ la administración e inversión de los caudales de propios y arbitrios conforme a las leyes y reglamentos; 
$4^{\circ}$ el repartimiento y la recaudación de las contribuciones;

$5^{\circ}$ el cuidado de las escuelas de primeras letras y los demás establecimientos de educación que se paguen con los fondos del común;

$6^{\circ}$ el cuidado de los hospitales, hospicios, casas de expósitos y establecimientos de beneficencia;

$7^{\circ}$ el cuidado de la construcción y reparación de los caminos, calzadas, puentes y cárceles, de los montes y plantíos del común y de las obras públicas de necesidad, utilidad y ornato;

$8^{\circ}$ la formación de las ordenanzas municipales para su aprobación por las Cortes, previo informe de la Diputación Provincial,

$9^{\circ}$ la promoción de la agricultura, la industria y el comercio y de cuanto les sea útil $y$ beneficioso.

De otro lado, aparecerán las competencias previstas en el artículo $6^{\circ}$ de la Instrucción, que podía conferir el Gobierno a los Ayuntamientos a través de los jefes políticos, con la inspección y controles ya citados de las Diputaciones. Como ya vimos y con acierto, Parejo dirá que de esta forma quedó consagrado el esquema revolucionario francés, que ha perdurado hasta nuestros días, de dualidad de las funciones municipales: las propias del ente local y las delegadas o atribuidas a éste por la Administración estatal ${ }^{53}$. Con igual criterio, el alcalde tendrá sus funciones propias como rector del municipio y se le atribuirán las competencias de orden público y seguridad ciudadana en el artículo 10.

La anterior enumeración de competencias nos confirma que estamos ante el desarrollo constitucional del artículo 321, que en la Instrucción se convierte en reglamentario. Sorprende la ausencia de criterios doctrinales para la asignación a los Ayuntamientos de estas atribuciones pues, como se ha reiterado, ni en los debates de la Instrucción, ni anteriormente en los de la Constitución se hizo referencia a las razones por las que se atribuyeron tales competencias a los Ayuntamientos y no otras.

Por ello, recurrimos a García Fernández quien señala la ausencia de un precepto delimitador de las competencias, análogo al artículo 49 del Decreto francés de 1789, reiterando la ignorancia sobre las razones de porque se llegó concretamente a esta relación de competencias, primero en el texto constitucional y después en la Instrucción de 1813, relacionándolo con el contenido del Libro VII de la Novísima Recopilación, de la que supone tomaron lo que les «pareció conveniente, sin orden ni concierto» ${ }^{54}$.

53 Parejo Alfonso, L., Derecho.... op. cit., pág. 31.

54 García Fernández, J., Los orígenes... op. cit., págs. 276-277. 
Para confirmarlo cotejaba los títulos contenidos en el libro VII de la Novísima cuya analogía con las competencias de 1812 y 1813 era prácticamente la misma. No debe sorprendernos esta similitud, ya observada en otras cuestiones, lo que nos llevó al establecimiento de un cuadro análogo al de García Fernández, comparando las atribuciones de los Intendentes en la Instrucción de 1746, las de los Jefes políticos en la Instrucción de 1823 y las asignadas a los Subdelegados de Fomento en el Decreto de $1833^{55}$.

Esta reiteración de coincidencias, nos hace plantear una vez más la presencia de instituciones jurídicas tradicionales en el ordenamiento constitucional. Sin embargo no perdamos de vista que en muchas ocasiones, y esta parece ser una de ellas, pues su relevo o desaparición estará en función principalmente de la dinámica social, del cambio y de las demandas de la misma sociedad. Distinta cuestión será el grado de autonomía para ejercerlas, la capacidad de autogobierno municipal. Conceptos en los que también podemos encontrar vestigios tradicionales, insertos en un ordenamiento enmarcado en la división de poderes.

De nuevo hemos de volver sobre el caso del alcalde. Dotado de la doble dimensión tradicional: gubernativa y judicial, aunque como sabemos, a partir de 1812 ésta tuvo menor incidencia que la primera. En otros aspectos de la configuración municipal, también están presentes diversos elementos de influencia francesa, y no precisamente de los orígenes revolucionarios, sino del posterior sistema napoleónico, diseñado en la Constitución de 1795 y en la ley francesa de 28 de pluvioso del año VIII. De modo, que el conjunto de normas e influencias legales que condicionaron el modelo centralizador de la Instrucción de 1813 lo esquematiza García Fernández en los siguientes términos:

- Competencias municipales: Novísima Recopilación

- Alcalde: Novísima Recopilación y ley de 28 de pluvioso del año VIII

- Jefe Político: Ley francesa del año VIII

- Diputaciones provinciales: Ley francesa del año VIII

- Procedimientos de tutela: Ley francesa del año VIII

- Uniformismo: Decreto francés de 1789

- Sistema electoral: Reformas de Carlos III e ideología democrática liberal de las Cortes de Cádiz ${ }^{56}$.

Como hemos visto, la normativa en materia local posterior a la promulgación de la Constitución de 1812, se inició con el Decreto de 23 de mayo de 1812 y se cerró con la Instrucción para el gobierno económico-político de las provincias de

55 Orduña Rebollo, E., Intendencias e Intendencias. Buenos Aires. Ciudad Argentina, 1996.

56 García Fernández, J., El origen... op. cit., pág. 300. 
23 de junio de 1813. En poco más de un año se dictaron unas normas «tipo puente» diríamos ahora, que renovaron la Administración municipal. Aunque al analizarlas con cierto detalle su propósito fundamentalmente está presidido por dos objetivos: la creación e instalación de Ayuntamientos constitucionales y la elección de los cargos. Junto a ello habrá una serie de cuestiones sobre procedimiento y funcionamiento que van recorriendo el camino de la normalización constitucional de los Ayuntamientos, entre las que señalaríamos, las incompatibilidades, proscripción de retribuciones, conflictos con los comisionados, cuestiones de competencias, etc., problemas en definitiva típicos de una administración que inicia su andadura.

El final de la guerra y el regreso a España de Fernando VII canceló toda la vigencia y actividad del régimen constitucional. La legislación represiva se inició con la derogación de la Constitución mediante el Decreto de 4 de mayo de 1814 expedido en Valencia y el retroceso a los imposibles postulados del Antiguo Régimen. A los efectos de nuestro trabajo, la cronología derogatoria siguió las siguientes pautas: Real Decreto de 15 de junio de 1814 suprimiendo las Diputaciones provinciales y ordenando que los papeles de sus secretarías pasasen a las respectivas Contadurías de provincia, incluyendo el restablecimiento del Consejo Real. El siguiente paso fue la promulgación de la Real Cédula de 30 de julio de 1814 ordenando la disolución y extinción de todos los Ayuntamientos y alcaldes constitucionales volviendo al sistema de Ayuntamientos, Corregimientos y Alcaldes mayores de acuerdo con la planta que existía en 1808 de acuerdo con el sistema tradicional.

La regresión era total, culminando la momentánea anulación del Régimen Constitucional con la Real Cédula de 29 de septiembre de 1814, disponiendo se reintegrasen los señoríos jurisdiccionales a su anterior situación, con lo que se producía la vuelta al Antiguo Régimen, aunque este último aspecto resultaría prácticamente inviable ante la fuerza que Audiencias y Chancillerías habían adquirido. Pero los vaivenes políticos van a marcar los próximos años del siglo XIX. Tras el período absolutista siguió el trienio constitucional de 1820 a 1823, que supuso la puesta en vigor de la Constitución de 1812 y en ese período, de nuevo fueron ejercidas las libertades públicas, hasta la intervención de Angulema y el ejército francés.

\section{f) La extensión de los Ayuntamientos Constitucionales}

Una referencia especial merece el proceso de instalación y generalización de Ayuntamientos, cuyas razones, como hemos indicado en diversas ocasiones, es- 
tuvo condicionada por la necesidad de sustituir los numerosos municipios y lugares de señorío — más del $50 \%$ del total— por Ayuntamientos constitucionales, lo que sin duda explica el elevado número que ha perdurado hasta nuestros días. En cuanto al ritmo de extensión de los Ayuntamientos, la realidad es que constituyó un lento proceso que se prolongó casi hasta mediados de siglo, pues en tal sentido reiterarán su necesidad diversas disposiciones como la Ley de 3 de febrero de 1823, el Real Decreto de 23 de julio de 1835 y la Ley de 8 de enero de 1845. Además debemos tener en cuenta que no todos los pueblos se convierten en Ayuntamientos y tales entidades de población quedan como recordaba Parejo «reducidos a la condición de unidades electorales para la formación de aquéllas» ${ }^{57}$.

Múltiples son las explicaciones que se darán para justificar las posibles razones del retraso: el tamaño, lentitud en el proceso de generalización de Ayuntamientos constitucionales, resistencias pasivas, escasa duración de los períodos constitucionales, etc. Tampoco el ritmo de oposición fue igual en unas regiones que en otras. En el norte, debido a una población diseminada fue más costoso; en León, Asturias, etc., el régimen de concejo abierto, recientemente estudiado, continuaría existiendo porque su vigor, democrático y popular, lo haría pervivir, pese a la ignorancia constitucional, en aldeas y pueblos y en tales Ayuntamientos, seguían rigiéndose por el sistema de concejo abierto, con vitalidad que llega hasta nuestros días y así reconoció en su día la Constitución de 1931 y ha reconocido la Constitución de 1978. En otras ocasiones sería un obstáculo, como apunta Luis Morell, «la tradición de un gobierno local unitario para valles o comarcas no rurales» ${ }^{58}$.

En el artículo I del Capítulo II de la mencionada Instrucción de 23 de junio de 1813, referido a las obligaciones y cargos de las Diputaciones Provinciales, figura que serán de su competencia:

«El cuidado del establecimiento de Ayuntamientos en los pueblos donde no lo haya»... $y$ «tomar razón exacta del vecindario de cada pueblo donde haya de establecerse Ayuntamiento para que sí llegase por sí o con su comarca a las 1.000 almas se establezca desde luego.»

También preveía el referido artículo que en caso de no llegar a tal número de habitantes, pero sí aconsejaban razones de interés público la conveniencia de establecerlo. Para ello, debía instruirse un expediente en tal sentido, acompañando los informes previos de los pueblos comarcanos sobre la designación de términos o cualquier pueblo donde debía establecerse un nuevo Ayuntamiento, por lo que

57 Parejo Alfonso, L., La región... op. cit., pág. 31.

58 Morell OCAÑA, L., El régimen local español. Madrid. 1988. 
es oportuno recordar que el diputado Aner, partidario de extender los Ayuntamientos al mayor número posible de pueblos, opinaba que: «las leyes llaman pueblo al que tenga 26 o 27 familias».

Conceptos parecidos a los de 1813, aparecen en el Decreto de 3 febrero de 1823, «Instrucción para el gobierno económico-político de las provincias», sancionada por el rey, como Ley, el 2 de marzo de 1823 aunque figura como Decreto de Cortes de 3 de febrero de dicho año, dividida en cuatro capítulos y 291 artículos, constituye un verdadero código de la Administración local ${ }^{59}$.

En esta ocasión eran los artículos 83 a 87 los que hacían referencia a la creación o supresión de Ayuntamientos por las Diputaciones, cuyas competencias en la materia quedaban definidas por la propia Instrucción. En virtud de lo dispuesto en el artículo 355 de la Constitución de Cádiz, debían proceder a su establecimiento en los pueblos donde no existiesen, para lo cual tomarían razón exacta del vecindario de cada pueblo y su comarca hasta contabilizar las 1.000 almas; en caso de que llegasen a esta cifra y por «razones de bien público conviniese establecerlo», la Diputación debía instruir el expediente que lo justificase.

En cualquier caso el expediente de creación de nuevos Ayuntamientos y el informe de la Diputación se trasladaban al Jefe político para su remisión al Gobierno. Idéntico procedimiento debía seguirse cuando se estimase la conveniencia de suprimir algún Ayuntamiento o agregarlos a otro próximo, bien por su escaso vecindario o por que lo solicitasen ellos mismos. En esta ocasión se consideraba el límite en 50 vecinos, aunque esta cifra no era óbice sí se consideraba conveniente la existencia del Ayuntamiento. Para valorar la procedencia de la supresión o el mantenimiento, en el expediente instruido por la Diputación provincial, debían hacerse constar los recursos del pueblo para sostener el Ayuntamiento, inconvenientes y ventajas de la agregación, distancia y facilidades de comunicación entre los pueblos agregados y acreditar los derechos, aprovechamientos, etc. que debían conservar los pueblos agregados.

La legislación local del constitucionalismo doceañista, en este aspecto fue generosa, porque se crearon Ayuntamientos en numerosos centros de escasa población. En cuanto a los menores de 1.000 almas que no solicitaron su transformación en Ayuntamientos o que los informes fueron negativos, siguieron agregados a los Ayuntamientos a que lo habían estado, «mientras que la mejora de su estado político no exija otra providencia», pero sin hacer otra previsión sobre su sistema de organización ni administración.

Simultáneamente se detecta un escaso desarrollo de los preceptos constitu-

59 Parejo Alfonso, L., Derecho básico de la Administración local. Barcelona. Ariel. 1988, pág. 33. 
cionales doceañistas en materia de organización del territorio local plasmado en este temprano e inexperto intento de la andadura municipalista, agobiado además el entorno político por el escaso margen de tiempo en que se desenvolvió el período de libertades públicas incipiente, pues un año después la reacción absolutista convertiría en papel mojado la obra del constitucionalismo doceañista.

Hemos de imaginar las dificultades que encontraron los agentes de las Diputaciones para materializar esta operación, donde además de las dificultades técnicas normales, tropezaron, por un lado, con la fuerza de los intereses privados de la jurisdicción señorial, por otro con las rivalidades entre los habitantes de los diversos núcleos de población que pugnaban por obtener la capitalidad del nuevo Ayuntamiento o las complicaciones para determinar los deslindes y los límites de cada término municipal, cuestión no baladí, que incluso en nuestros días tienen que resolver los tribunales de justicia.

La articulación legal de los núcleos territoriales y de población inferiores al municipio en el período postconstitucional no resulta muy explícita; sólo encontraremos algunas referencias dirigidas a motivar la agrupación de pueblos para constituir Ayuntamientos. En este sentido el mencionado Decreto de 23 de mayo de 1812, disponía que las Diputaciones informasen al Gobierno sobre la existencia de pueblos sin Ayuntamientos, con población inferior a las 1000 almas prefijadas, pero dotadas de medios comerciales, agrarios o industriales, para que resolviese lo conveniente. También preveía que la elección de alcaldes se hiciese por medio de juntas parroquiales, agrupándose varias parroquias en el caso de que los pueblos no reuniesen la cifra mínima de cincuenta vecinos.

Las referencias son un poco más amplias en la Instrucción de 1823, en muchos sentidos considerada como la primera Ley de Régimen Local del municipio constitucional, dichas menciones están contenidas en el Capítulo III referido a los alcaldes. Hay un reconocimiento explícito a la existencia de unidades territoriales y de población (barrios, aldeas, lugares, caseríos separados) que no reúnen la condición legal de Ayuntamiento, pero están consideradas como parte integrantes de éste, quien designaría un Capitular vecino de ellos, o en su ausencia un Celador para tomar providencias urgentes y dar cuenta a los Alcaldes de los asuntos que lo requiriesen, con lo que se perfilaba según Flórez de Quiñones una sustitución del centralismo del Estado por la del Ayuntamiento. También en el procedimiento electoral se regulaba el sistema de Juntas parroquiales como en la norma de 1812.

Hemos hecho mención anteriormente al desconocimiento del número de Ayuntamientos a partir de 1812, situación que continuó durante el trienio liberal y en los años sucesivos. La duda partía de las 19.450 entidades de población según consta en España dividida en Provincias de 1789. Se estimó que después de 
1812 había unos 12.000 municipios. Posteriormente la cifra de 15.269 pueblos según consta en el decreto de división de España en Partidos judiciales de 1834, se ha descartado siempre por diversos autores al considerarla exagerada. Habrá que esperar al Censo de 1842, realizado por los Jefes Políticos, con el título de Matrícula Catastral, que suponía la existencia de 11.271 municipios, entre los que constaban 2.703 inferiores a 30 vecinos. Cuestionada la cifra por los Intendentes y por Pascual Madoz, habrá que espera al censo de 1857, después de depurar los datos anteriores y desaparecer 1.916 municipios entre los referidos años de 1842 y 1857 para establecer el dato definitivo en 9.355 Ayuntamientos, de los que han llegado a nuestro días 8.116.

A propósito de esta información, recordemos el esfuerzo del Diccionario Geográfico (1845-1850) de Pascual Madoz, el cual, si bien es un verdadero monumento e impresionante banco de datos municipal para su tiempo, también es un hecho constatado que se encuentran múltiples errores e inexactitudes y su fiabilidad en cuanto a asuntos concretos no es muy clara. Entre ellos el número de municipios. Creemos que para el cómputo más riguroso es el del Censo de 1842 y de forma definitiva el de 1857 para determinar más exactamente los aspectos poblacionales del municipio español.

En definitiva, el Municipio del Antiguo Régimen se transforma en Municipio Constitucional a partir de 1812, pero éste conserva pocas similitudes, excepto el nombre con aquel. Se abre entonces una andadura que llega a nuestros días. La institución que inicialmente se concibió como un agente del Estado en el territorio, irá transformándose en una entidad dotada de competencias propias y autonomía para el ejercicio de estas competencias. El hecho de que la Constitución doceañista estuviese en vigor escasos años y la Instrucción para el Gobierno económico-político de las Provincias de 1823, el desarrollo constitucional más importante referida al Municipio, tuviese sólo una vigencia intermitente que en conjunto no superó los 10 años de un total de treinta y tres, no supuso de ninguna forma la quiebra del modelo de Municipio Constitucional.

A lo largo de dos siglos, ha sido ejemplo de supervivencia, desde períodos iniciales de protagonismo cuasi revolucionario, hasta fases de consolidación moderada, el Municipio Constitucional fue adquiriendo las condiciones que le configuraron como una administración local, pese o quizá merced, al control gubernativo. Superó el lastre de los sistemas electorales censitarios, hasta la implantación a finales del siglo XIX del sufragio universal, excluidas las mujeres, posteriormente discurriría su andadura por épocas de limitaciones propias de autoritarismos o dictaduras, que alterarían el sistema electoral, resucitando viejos conceptos periclitados o se incrementaron los controles con suspensiones y demás limitaciones. Pero pese a tales limitaciones no se modificó su esencia, contenido 
o funciones, el Municipio siguió siendo la base de la organización territorial del Estado y como se dice ahora la administración más próxima al ciudadano.

Title:

THE CONSTITUTIONAL MUNICIPALITY IN THE 1812 SPAIN

\section{Summary:}

1. BETWEEN THE INSTITUTIONAL CHANGE OR THE RUPTURE. a) The fleeting municipal legislation of Jose I. b) The josefino decree of division in prefectures and municipal government. 2. THE MUNICIPALITIES IN THE DAWN OF THE SPANISH CONSTITUCIONALISMO. a) The commission of constitution and consulta to the country. b) The josefino decree of division in prefectures and municipal government. c) The city councils in the transaction of the project of constitution of 1812. d) The city councils in the constitutional text. e) The ephemeral constitutional development of the legislation of the city councils. f) The extension of the constitutional city councils.

\section{Resumen:}

El artículo tiene por objeto el estudio de la institución municipal en la Constitución de Cádiz de 1812. Principia la exposición analizando el modelo de municipio propugnado por gobierno bonapartista caracterizado por el acendrado centralismo contrario a cualquier destello de autonomía municipal. El régimen municipal de la Carta Magna gaditana - Título VI- pretendía abolir los señoríos y la venta de oficios públicos, y las normas jurídicas —Decretos de 23 de mayo de 1812 y de 23 de junio de 1813 — aprobadas después de la Constitución renovaron la Administración municipal tratando de lograr dos objetivos: la creación e instalación de Ayuntamientos constitucionales y la elección de los cargos junto con cuestiones de tipo procedimental y de funcionamiento que van recorriendo el camino de normalización constitucional de los Ayuntamientos, que se malograron con el regreso a España de Fernando VII y la subsiguiente derogación de la Constitución gaditana y la vuelta al absolutismo.

\section{Abstract:}

The article aims to study the municipal institution in the Cadiz Constitution of 1812. Exposure begins by analyzing the model advocated by bonapartist government municipality characterized by the pure 
centralism against any glimmer of municipal autonomy. The municipal system of the Cadiz Constitution, Title VI, wished to abolish the estates and the sale of public offices, and legal regulations, decrees of May 23, 1812 and June 23, 1813 - adopted after the Constitution renewed the municipal administration trying to achieve two objectives: the creation and installation of constitutional councils and the election of the charges together with matters of a procedural nature and are operating following the path of constitutional normalization of the municipalities, who went wrong with the return to Spain Fernando VII and the subsequent repeal of the Cadiz Constitution and a return to absolutism.

\section{Palabras clave:}

Ayuntamiento, municipio, sufragio e igualdad.

Key words:

Council, municipality, suffrage and equality. 
